\title{
THE EFFECT OF TEMPORARY OCCLUSION OF ARTERIOVENOUS FISTULAS ON HEART RATE, STROKE VOLUME, AND CARDIAC OUTPUT ${ }^{1}$
}

\author{
By JOHN L. NICKERSON, DANIEL C. ELKIN, AND JAMES V. WARREN \\ (From the Departments of Medicine and Surgery, Emory University School of Medicine, \\ Atlanta, Georgia; the Department of Physiology of the College of Physicians and \\ Surgeons, Columbia University, New York; and the Vascular Surgery Center, \\ Ashford General Hospital, White Sulphur Springs, West Virginia)
}

(Submitted for publication October 21, 1950; accepted, November 20, 1950)

In patients with an arteriovenous fistula temporary occlusion of the fistula results in several alterations in the circulation. The most commonly recognized of these is the slowing of the heart rate. This response, described originally in 1875 by Nicoladoni (1), was reported independently in 1890 by Branham (2). It is now almost universally referred to as Branham's sign. Subsequently, additional changes in arterial pressure (3), cardiac output $(4,5)$ and peripheral blood flow (6) have been noted by other authors. In the course of our studies on the cardiovascular dynamics in patients with arteriovenous fistulas we have made further observations on Branham's sign and related phenomena. These data are the subject of the present report.

\section{METHODS}

The critically damped ballistocardiograph described by Nickerson and Curtis (7) was used in the determination of heart rate, stroke volume, and cardiac output. The method of its use is described in a separate report (5). Only patients with arteriovenous fistulas of the extremities were studied. The fistula was obliterated temporarily by rapid inflation of a blood pressure cuff to $200 \mathrm{~mm}$. mercury pressure from a large air reservoir. The cuff was placed around the extremity in such a way that deflation did not affect the venous blood flow. This was done several times before taking the ballistic records in order to familiarize the patient with the procedure and to ascertain if there was discomfort upon application of pressure in the cuff. Ballistic tracings and arterial blood pressure measurement (determined by the auscultatory method) were obtained with the fistula both open and occluded. At least two sets of observations were made on each patient. In some instances $2 \mathrm{mgm}$. of atropine sulfate were injected intravenously, and the observations

1 The work described in this paper was done under a contract, recommended by the Committee on Medical Research, between the Office of Scientific Research and Development and the Emory University School of Medicine, Atlanta, Georgia. were repeated at the height of the atropine effect. Additional studies were made following operative removal of the arteriovenous fistula.

\section{RESULTS}

Twenty-five patients with arteriovenous fistulas resulting from trauma were studied. The studies were restricted to those patients with fistulas of the extremities which could be occluded by inflation of a blood pressure cuff. None of the patients had clinical evidence of cardiac failure, or any disease which might alter the responses of the cardiovascular system. All of the patients reported here have been included in a previously reported study on the cardiac output in patients with arteriovenous fistulas (5).

Observations on the effect of sudden occlusion of an arteriovenous fistula are recorded in Table $\mathrm{I}$ and shown graphically in Figure 1 . In 17 pa-

\section{GHANGE IN CARDIAC OUTPUT UPON TEMPORARY OCCLUSION OF A-V FISTULA}

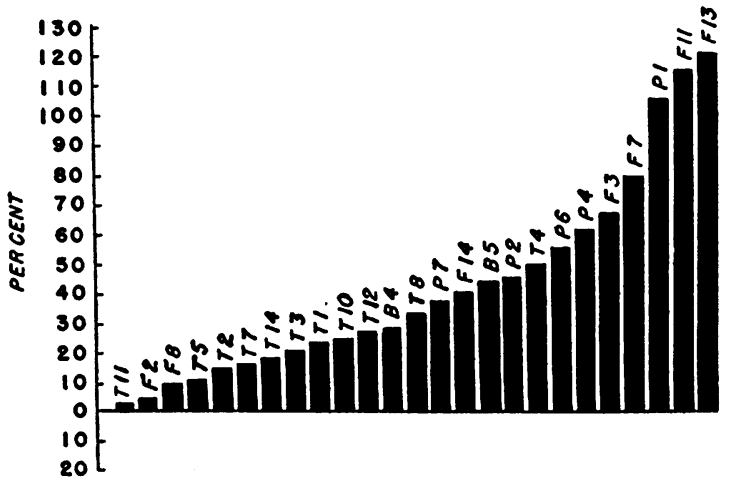

Fig. 1. Changes in Cardiac Output upon Temporary Occlusion of A-V Fistula

The cardiac output with the fistula open is expressed in per cent deviation from the cardiac output with the fistula occluded. 
JOHN L. NICKERSON, DANIEL C. ELKIN, AND JAMES V. WARREN

TABLE I

Summary of observations on 25 patients with arteriovenous fistulas of the extremities

\begin{tabular}{|c|c|c|c|c|c|c|c|}
\hline $\begin{array}{l}\text { Location of fistula } \\
\text { and number of } \\
\text { patients in group }\end{array}$ & $\begin{array}{l}\text { Duration of } \\
\text { fistula }\end{array}$ & $\begin{array}{c}\text { Time of } \\
\text { observation }\end{array}$ & Comment & $\begin{array}{c}\text { Cardiac } \\
\text { index }\end{array}$ & $\begin{array}{l}\text { Stroke } \\
\text { volume }\end{array}$ & $\begin{array}{l}\text { Pulse } \\
\text { rate }\end{array}$ & $\begin{array}{l}\text { Arterial } \\
\text { pressure }\end{array}$ \\
\hline $\begin{array}{l}\text { Brachial } \\
\text { (2) }\end{array}$ & $\begin{array}{c}\text { months } \\
4\end{array}$ & $\begin{array}{c}\text { days before and } \\
\text { after operation } \\
4 \text { before } \\
5 \text { before } \\
9 \text { after }\end{array}$ & $\begin{array}{l}\text { Cuff off } \\
\text { Cuff on }\end{array}$ & $\begin{array}{c}\text { liters per min. } \\
\text { per sq. m. } \\
4.8 \\
3.4 \\
4.0\end{array}$ & $\begin{array}{c}c c . \\
126.5 \\
115.5 \\
105.9\end{array}$ & $\begin{array}{c}\text { beats per min. } \\
70.4 \\
54 \\
68.8\end{array}$ & $\begin{array}{l}m m . H g \\
128 / 79 \\
125 / 80 \\
122 / 66\end{array}$ \\
\hline$\underset{(7)}{\text { Femoral }}$ & 4.1 & $\begin{array}{l}6 \text { before } \\
4 \text { before } \\
15 \text { after }\end{array}$ & $\begin{array}{l}\text { Cuff off } \\
\text { Cuff on }\end{array}$ & $\begin{array}{l}5.7 \\
3.6 \\
3.5\end{array}$ & $\begin{array}{r}132.8 \\
104.9 \\
93.0\end{array}$ & $\begin{array}{l}77.4 \\
61.4 \\
69.8\end{array}$ & $\begin{array}{l}119 / 90 \\
118 / 73 \\
115 / 74\end{array}$ \\
\hline $\begin{array}{l}\text { Popliteal } \\
(5)\end{array}$ & 9.6 & $\begin{array}{l}9 \text { before } \\
11 \text { before } \\
17 \text { after }\end{array}$ & $\begin{array}{l}\text { Cuff off } \\
\text { Cuff on }\end{array}$ & $\begin{array}{l}4.9 \\
3.7 \\
4.8\end{array}$ & $\begin{array}{l}135.4 \\
102.5 \\
103.8\end{array}$ & $\begin{array}{l}65.9 \\
55.8 \\
65.6\end{array}$ & $\begin{array}{l}118 / 57 \\
117 / 81 \\
115 / 48\end{array}$ \\
\hline $\begin{array}{r}\text { Tibial } \\
(11)\end{array}$ & 8.2 & $\begin{array}{l}6 \text { before } \\
7 \text { before } \\
23 \text { after }\end{array}$ & $\begin{array}{l}\text { Cuff off } \\
\text { Cuff on }\end{array}$ & $\begin{array}{l}4.0 \\
3.2 \\
3.6\end{array}$ & $\begin{array}{r}107.5 \\
91.9 \\
95.5\end{array}$ & $\begin{array}{l}67.8 \\
63.4 \\
68.4\end{array}$ & $\begin{array}{l}122 / 75 \\
124 / 79 \\
114 / 66\end{array}$ \\
\hline
\end{tabular}

tients ( 68 per cent) the heart rate decreased more than 4 beats per minute and in one case as much as 32 beats per minute. In the remaining eight cases the rate changed only 4 or less beats per minute. In 19 patients (76 per cent) stroke vol- ume decreased $10 \mathrm{cc}$. or more per stroke. The effects on the cardiac index (cardiac output in liters per minute per square meter of body surface) varied from no change to a decrease of 3.6 liters. In 22 patients ( 88 per cent) it decreased 0.5 liters

TABLE II

Observation of the effect of temporary occlusion of an arteriovenous fistula before and after administration of atropine

\begin{tabular}{|c|c|c|c|c|c|c|}
\hline $\begin{array}{c}\text { Location of fistula } \\
\text { patient }\end{array}$ & Comment & $\begin{array}{l}\text { Cardiac } \\
\text { output }\end{array}$ & $\begin{array}{c}\text { Cardiac } \\
\text { index }\end{array}$ & $\begin{array}{l}\text { Stroke } \\
\text { volume }\end{array}$ & $\begin{array}{c}\text { Heart } \\
\text { rate }\end{array}$ & $\begin{array}{l}\text { Arterial } \\
\text { pressure }\end{array}$ \\
\hline$\underset{(7)}{\text { Femoral }}$ & $\begin{array}{l}\text { Cuff off } \\
\text { Cuff on } \\
\text { Atropine-2 mgm. intravenously } \\
\text { Cuff off } \\
\text { Cuff on }\end{array}$ & $\begin{array}{c}\text { liters per min. } \\
10.3 \\
6.5 \\
12.3 \\
8.6\end{array}$ & $\begin{array}{c}\text { liters per min. } \\
\text { per sq. } \mathrm{m} \text {. } \\
5.8 \\
3.7 \\
\\
7.0 \\
4.9\end{array}$ & $\begin{array}{r}c c . \\
124 \\
107 \\
123 \\
83\end{array}$ & $\begin{array}{c}\text { beats per min. } \\
83 \\
61 \\
100 \\
104\end{array}$ & $\begin{array}{l}m m . H g \\
110 / 60 \\
115 / 70 \\
125 / 85 \\
145 / 95\end{array}$ \\
\hline$\underset{(13)}{\text { Femoral }}$ & $\begin{array}{l}\text { Cuff off } \\
\text { Cuff on } \\
\text { Atropine-2 mgm. intravenously } \\
\text { Cuff off } \\
\text { Cuff on }\end{array}$ & $\begin{array}{r}12.0 \\
6.1 \\
9.7 \\
7.9\end{array}$ & $\begin{array}{l}6.5 \\
3.3 \\
5.3 \\
4.3\end{array}$ & $\begin{array}{r}158 \\
139 \\
105 \\
84\end{array}$ & $\begin{array}{l}76 \\
44 \\
93 \\
94\end{array}$ & $\begin{array}{l}120 / 55 \\
125 / 70 \\
130 / 85 \\
150 / 90\end{array}$ \\
\hline $\begin{array}{l}\text { Popliteal } \\
\text { (4) }\end{array}$ & $\begin{array}{l}\text { Cuff off } \\
\text { Cuff on } \\
\text { Atropine-2 mgm. intravenously } \\
\text { Cuff off } \\
\text { Cuff on }\end{array}$ & $\begin{array}{r}11.6 \\
6.8 \\
15.6 \\
12.1\end{array}$ & $\begin{array}{l}6.0 \\
3.5 \\
8.0 \\
6.2\end{array}$ & $\begin{array}{l}140 \\
110 \\
127 \\
102\end{array}$ & $\begin{array}{r}83 \\
62 \\
123 \\
119\end{array}$ & $\begin{array}{l}115 / 60 \\
115 / 70 \\
135 / 90 \\
140 / 100\end{array}$ \\
\hline $\begin{array}{l}\text { Popliteal } \\
(6)\end{array}$ & $\begin{array}{l}\text { Cuff off } \\
\text { Cuff on } \\
\text { Atropine-2 mgm. intravenously } \\
\text { Cuff off } \\
\text { Cuff on }\end{array}$ & $\begin{array}{l}5.8 \\
4.2 \\
8.8 \\
6.4\end{array}$ & $\begin{array}{l}3.6 \\
2.6 \\
5.5 \\
4.0\end{array}$ & $\begin{array}{l}93 \\
70 \\
86 \\
62\end{array}$ & $\begin{array}{r}62 \\
59 \\
102 \\
102\end{array}$ & $\begin{array}{l}110 / 60 \\
115 / 75 \\
120 / 65 \\
130 / 85\end{array}$ \\
\hline $\begin{array}{c}\text { Tibial } \\
\text { (4) }\end{array}$ & $\begin{array}{l}\text { Cuff off } \\
\text { Cuff on } \\
\text { Atropine- }-2 \mathrm{mgm} \text {. intravenously } \\
\text { Cuff off } \\
\text { Cuff on }\end{array}$ & $\begin{array}{l}9.4 \\
6.9 \\
9.8 \\
5.6\end{array}$ & $\begin{array}{l}5.0 \\
3.6\end{array}$ & $\begin{array}{r}132 \\
120 \\
100 \\
59\end{array}$ & $\begin{array}{l}71 \\
57\end{array}$ & $\begin{array}{l}120 / 60 \\
120 / 80 \\
140 / 90 \\
160 / 100\end{array}$ \\
\hline
\end{tabular}


or more, which, under the conditions of the study, probably represents a minimal detectable change. Changes in arterial pressure were not large, but almost uniformly consisted of an increase in diastolic pressure and frequently an increased systolic pressure upon occlusion of the fistula.'

Additional studies on the effect of compression of the fistula were made on five patients who had received intravenously $2 \mathrm{mgm}$. of atropine sulfate (Table II). In all the atropine produced an increased pulse rate and in some an increase in cardiac index above the basal level. Upon inflation of the cuff the change in pulse rate was not greater than 4 beats per minute. Despite this relatively small change in heart rate, the decrease in stroke volume varied from 21 to $41 \mathrm{cc}$. and in cardiac output from 1.8 to 4.2 liters.

\section{DISCUSSION}

The advantages of the ballistic method for determination of relatively rapid changes in cardiovascular dynamics have been enumerated previously $(5,8)$. One disadvantage in the use of the ballistocardiograph is that manual compression of the fistula interferes with the movements of the ballistic bed. Therefore, a blood pressure cuff was used. This means of temporarily occluding the fistula occludes not only the fistula but also all of the circulation to the extremity distal to the cuff.

Studies on normal subjects, and on normal extremities of patients with arteriovenous fistula elsewhere in the body, have shown that rapid inflation of the cuff to $200 \mathrm{~mm}$. mercury pressure produced practically no change in cardiac output or pulse rate. In one patient, in whom the fistula was also occluded with a Matas compressor (compression of only the major vessel entering the fistula) (9), it was found that the cuff and compressor produced identical changes in heart rate and cardiac output.

The findings reported here confirm Branham's observations. The rapidity of the reaction suggests that a nervous reflex is involved. Lewis and Drury (6) observed that they could block the reaction by the preliminary administration of atropine. Rieder (10) was unable to confirm this, but it is likely that his dosage of atropine was inadequate. The present results confirm the findings of Ellis and Weiss (11), and of Kramer and Kahn (12), that atropinization can block the change in pulse rate. This effect of atropine was interpreted as evidence that the pulse slowing response is mediated by a nervous mechanism, and by the vagus nerve in particular.

The specific stimulus which activates the bradycardiac response is not completely understood. It has been suggested that the vascular bed in and around the fistula may take on a function similar to the carotid sinus or aortic depressor areas in that local pressure changes are reflected in reflex changes in cardiac function. This does not appear to be the case. Observations $(13,14)$ have revealed that the pulse rate changes occur in patients with high spinal anesthesia. In these patients the area of the fistula is probably devoid of functional nervous connections, but it is not certain that complete denervation is present.

Several other systemic circulatory alterations take place when an arteriovenous fistula is occluded. Measurements of the pressure in the right atrium have failed to show any alteration, whereas the arterial pressure is found to rise. The latter phenomenon offers the most likely explanation for the slowing of the pulse rate. It is an established physiologic principle (Marey's law) that the pulse slows when the blood pressure rises. The origin of this type of reflex response appears to occur in the pressure sensitive end organs in the carotid sinus and aortic arch. In addition, experience in normal human subjects has shown that drugs which cause an increased arterial pressure with little change in cardiac output, such as paredrine, usually cause a slowing in the heart rate (15).

The present observations also demonstrate a striking decrease in stroke volume upon compression of the fistula. As a result of the summation of changes in heart rate and stroke volume the cardiac output is reduced. However, the reduction in stroke volume appears to be independent of the pulse rate change. Atropine, which abolishes the heart rate change, does not prevent the reduction in stroke volume. In fact, in the cases observed, the stroke volume reduction in occlusion of the fistula is greater with atropine than without. This effect is probably the result of the shorter filling time which is a consequence of the higher heart rate during atropinization.

The nature of the mechanism responsible for the change in stroke volume upon opening or 
closing the fistula is of considerable interest. The change occurs rapidly, significant alterations appearing within the first few heart beats. Theoretically it appears that the stroke volume may be altered by one of three mechanisms : changes in the pressure gradient filling the ventricles, variation in the completeness of systolic emptying of the ventricles, and variation in the degree of diastolic relaxation of the ventricles.

Studies using the method of right heart catheterization have revealed evidence regarding the first possibility. It has been demonstrated (16) that there is no change in the mean right atrial pressure when the fistula is opened and closed, although there may be large changes in stroke volume. Changes in atrial pressures do not then appear to be the cause of the increased stroke volume. Nevertheless, one qualification remains in that a pressure gradient cannot be determined by measuring the pressure at a single point in the system. Pressure in the ventricle may change, hence the gradient filling the ventricle would be altered.

There is, however, no direct evidence regarding the completeness of systolic emptying and the changes in diastolic relaxation of the ventricles in normal man. In addition to invoking the passive increase of fluid movement on opening the fistula as an explanation of the increased stroke volume there is the possibility of involvement of some nervous mechanism. Such a mechanism may influence the degree of relaxation of the ventricles, and the necessary stimulus could originate in the venous bed. If a nervous reaction is involved, it must occur rapidly and not be blocked by atropine.

Changes in cardiac output and stroke volume similar to these reported here may be observed in normal subjects by the production of large areas of reactive hyperemia (16). If blood pressure cuffs are placed around the upper thighs and inflated to $200 \mathrm{~mm}$. mercury pressure, little change in heart rate and cardiac output is produced. If the tourniquets are kept on for 20 minutes, and observations are made at the time of release, striking changes in heart rate and output may be noted. The heart rate increases, and the cardiac output per minute almost doubles. These changes, as those in our patients with arteriovenous fistulas, occurred without significant alterations in atrial pressure.
After operative removal of the fistula the cardiac output was found to be nearly the same as that observed previously upon temporary compression of the fistula. Cardiac output is such a variable function, changing markedly with even emotional factors, that it is difficult to say whether the failure of the values to coincide exactly always represents a real difference in output as related to the length of time that the fistula is closed, or whether it represents variations in the conditions under which the values were obtained.

\section{SUMMARY AND CONCLUSIONS}

The changes in heart rate and output occurring upon temporary compression of an arteriovenous fistula have been studied in a group of 25 patients.

In 68 per cent of the patients there was a significant decrease in heart rate (Branham's sign) which occurred almost immediately upon compression of the fistula and which was blocked by use of atropine.

In 88 per cent of the patients there was a decrease in stroke volume and cardiac output which occurred rapidly and simultaneously, but which was not altered by the use of atropine.

The evidence indicates that the change in heart rate results from a nervous reflex mediated by the vagus nerve, and most likely arises from alterations in arterial pressure. It appears that the change in stroke volume is due to variations in diastolic relaxation of the ventricle or to variation in the completeness of systolic emptying.

Although exactly comparable observations are difficult to obtain, the cardiac output found immediately upon closure of an arteriovenous fistula is approximately the same as that found several weeks after operative removal of the fistula.

Misses Mary Margaret Steele and Maurine Giese gave valuable technical assistance.

\section{REFERENCES}

1. Nicoladoni, C., Phlebarteriectasie der rechten oberen Extemitat. Arch. f. klin. Chir., 1875, 18, 252.

2. Branham, H. H., Aneurismal varix of the femoral artery and vein following a gunshot wound. Internat. J. Surg., 1890, 3, 250.

3. Holman, E., Arteriovenous Aneurysm; Abnormal Communications Between the Arterial and Venous Circulations. Macmillan Co., New York, 1937.

4. Kennedy, J. A., and Burwell, C. S., Measurements of the circulation in a patient with multiple arteriovenous connections. Am. Heart J., 1944, 28, 133. 
5. Warren, J. V., Nickerson, J. L., and Elkin, D. C., The cardiac output in patients with arteriovenous fistulas. J. Clin. Invest., 1951, 30, 210.

6. Lewis, T., and Drury, A. N., Observations relating to arteriovenous aneurysm; circulating manifestations in clinical cases with particular reference to arterial phenomena of aortic regurgitation. Heart, 1923, 10, 301.

7. Nickerson, J. L., and Curtis, H. J., The design of the ballistocardiograph. Am. J. Physiol., 1944, 142, 1.

8. Nickerson, J. L., Warren, J. V., and Brannon, E. S., The cardiac output in man: studies with the low frequency, critically-damped ballistocardiograph, and the method of right atrial catheterization. J. Clin. Invest., 1947, 26, 1.

9. Matas, R., Testing the efficiency of the collateral circulation as a preliminary to the occlusion of the the great surgical arteries; further observations, with special reference to the author's methods, including a review of other tests thus far suggested. J.A.M.A., 1914, 63, 1441.
10. Rieder, W., Herzschadigung infolge arterio-venosen aneurysmas. Arch. f. klin. Chir., 1926, 139, 597.

11. Ellis, L. B., and Weiss, S., The local and systemic effects of arteriovenous fistula on the circulation of man. Am. Heart J., 1929, 5, 635.

12. Kramer, M. L., and Kahn, J. W., Effect of atropine on the Branham sign in arteriovenous fistula. Arch. Int. Med., 1946, 78, 28.

13. Gerlach, F., and Harke, W., Ein Beitrag zur Frage der Entstehung der Blutdruckstergerung und Pulsverlangsamung bei Kompression arteriovenoser Aneurysmen. Klin. Wchnschr., 1924, 3, 980.

14. Elkin, D. C., Unpublished observations.

15. Ranges, H. A., and Bradley, S. E., Systemic and renal circulatory changes following the administration of adrenin, ephedrine, and paredrinol to normal man. J. Clin. Invest., 1943, $22,687$.

16. Stead, E. A., Jr., and Warren, J. V., Cardiac output in man; an analysis of the mechanisms varying the cardiac output based on recent clinical studies. Arch. Int. Med., 1947, 80, 237. 